\title{
Bakteri Penyebab Otitis Media Supuratif Kronis di Rumah Sakit Umum Universitas Kristen Indonesia
}

\author{
Tio Dora Parhusip, ${ }^{1}$ Bambang Suprayogi Resi Utomo, ${ }^{*}$ Lina Marlina, ${ }^{1}$ \\ Fransiscus Harp Poluan, ${ }^{1}$ Jurita Falorin, ${ }^{1}$ Adli Nurfachri, ${ }^{1}$ Dame Joice Pohan ${ }^{2}$
${ }^{1}$ Departemen Ilmu Penyakit Telinga Hidung Tenggorok Kepala Leher Fakultas Kedokteran Universitas Kristen Indonesia Jakarta.
${ }^{2}$ Departemen Mikrobiologi Fakultas Kedokteran Universitas Kristen Indonesia Jakarta.

\begin{abstract}
Abstrak
Otitis media supuratif kronis (OMSK) merupakan inflamasi dari telinga tengah dan rongga mastoid kronis, ditandai dengan perforasi membran timpani serta cairan yang keluar dari telinga secara persisten. Gangguan pendengaran dan kecacatan umumnya disebabkan oleh OMSK. Komplikasi otitis media supuratif kronis lainnya dapat menyebabkan infeksi intrakranial yang fatal dan mastoiditis akut, terutama di Negara-negara berkembang. Penatalaksanaan yang efektif tergantung pada pengetahuan mengenai mikroorganisme penyebab dan sensitivitas mikroba. Penelitian ini bertujuan untuk mengetahui pola bakteri penyebab otitis media supuratif kronis di Rumah Sakit Umum Universitas Kristen Indonesia Tahun 2019. Metode penelitian yang digunakan adalah deskriptif dengan pendekatan secara clinical series yang dilakukan dari bulan Agustus 2019 sampai November 2019 di Poliklinik THT-KL RSU UKI dan Laboratorium Mikrobiologi FK UKI. Hasil dari 17 sampel menunjukkan bahwa Staphylococcus aureus merupakan bakteri terbanyak yang ditemukan pada penderita OMSK yaitu 6 (35,3\%), diikuti Pseudomonas aerugenosa 5 (29,4\%), Staphylococcus epidermidis 2 (11,8\%), Klebsiella spp. 2 (11,8\%), Proteus spp. 1 (5,9\%), Escherichia coli 1 (5,9\%).
\end{abstract}

Kata kunci :otitis media supuratif kronis, pola bakteri.

\section{The Etiology of Chronic Suppurative Otitis Media at the UKI General Hospital}

\begin{abstract}
Chronic suppurative otitis media (CSOM) is a chronic inflammation of the middle ear and mastoid cavity, followed with recurrent ear discharges or otorrhoea through a tympanic perforation. Hearing impairment and disability are generally caused by CSOM. Other complications of chronic suppurative otitis media can lead to fatal intracranial infections and acute mastoiditis, especially in developing countries. Effectivity of the disease management depends on the knowledge of causative microorganisms and their antimicrobial sensitivity. The purpose of this study is to identify the bacterial pattern that cause chronic suppurative otitis media in Christian University of Indonesia General Hospital in 2019. This study is using the descriptive method with a clinical series approach, this study was carried out from August 2019 to November 2019 at the polyclinic of ENT-HNS RSU UKI and Microbiology Laboratory FK UKI. The results of 17 samples showed Staphylococcus aureus was the most bacteria found in CSOM patient 6 samples (35,3\%), followed Pseudomonas aerugenosa 5 (29,4\%), Staphylococcus epidermidis 2 (11,8\%), Klebsiella spp. 2 (11,8\%), Proteus spp. 1 (5,9\%), Escherichia coli 1 $(5,9 \%)$.
\end{abstract}

Keywords: chronic suppurative otitis media, bacterial pattern

*BSRU: Penulis Koresponden; E-mail: bambangsurpayogi@ rocketmail.com 


\section{Pendahuluan}

Otitis media supuratif kronis (OMSK) merupakan inflamasi dari telinga tengah dan rongga mastoid kronis, ditandai dengan perforasi dari membran timpani serta cairan yang keluar dari telinga secara persisten. Umumnya pasien dengan cairan yang keluar dari telinga melalui membran timpani secara terus menerus dengan periode waktu dari $6-12$ minggu dapat didiagnosis sebagai OMSK. ${ }^{1}$ Otitis media supuratif kronis (OMSK) biasanya merupakan komplikasi dari otitis media akut yang terjadi pada anak-anak. ${ }^{2}$ Gangguan pendengaran dan kecacatan umumnya disebabkan oleh OMSK. Otitis media supuratif kronis (OMSK) menyumbang lebih dari 50\% kasus gangguan pendengaran konduktif ringan hingga sedang. Gangguan pendengaran pada anak-anak berdampak dalam perkembangan bahasa, fungsi kognisi, psikososial dan pendidikan. ${ }^{2,3}$ Komplikasi Otitis media supuratif kronis (OMSK) lainnya dapat menyebabkan infeksi intrakranial yang fatal dan mastoiditis akut, terutama di Negara-negara berkembang. ${ }^{2}$

World Health Organization (WHO) menunjukkan prevalensi Otitis media supuratif kronis (OMSK) di dunia menunjukkan beban dunia karena penyakit tersebut berkisar 65-330 juta penderita, 60\% diantaranya (39-200 juta) mengalami gangguan pendengaran yang signifikan.Prevalensi Otitis media supuratif kronis (OMSK) di Negara berkembang masih tinggi yaitu sekitar 2-4\%. Sekitar 164 juta kasus gangguan pendengaran disebabkan OMSK, $90 \%$ terjadi di Negara berkembang. ${ }^{1}$ Infeksi saluran napas atas yang berulang, kondisi sosial ekonomi, kebersihan dan nutrisi yang buruk sering dikaitkan dengan perkembangan OMSK. ${ }^{2}$ Menurut data RISKESDAS tahun 2013, prevalensi gangguan pendengaran secara nasional adalah 2,6\%, dengan prevalensi tertinggi di provinsi NTT $(3,6 \%)$ sedangkan terendah di provinsi Banten (1,6\%). ${ }^{4}$ Di Rumah Sakit Dr. Hasan Sadikin, Bandung jumlah pasien OMSK pada tahun 2011 adalah 117 pasien dan 43 pasien mengalami komplikasi. ${ }^{5}$ Berdasarkan penelitian di Poliklinik THT-KL RSUP Prof. Dr. R. D. Kandou Manado selama periode 3 tahun (2014-2016), didapatkan jumlah pasien yang menderita OMSK adalah 78 pasien, dengan kasus terbanyak pada tahun 2016 yaitu 45 kasus, dan yang paling sedikit pada tahun 2014 yaitu 15 kasus, sedangkan di tahun 2015 didapatkan 18 kasus. ${ }^{6}$

Pada Otitis media supuratif kronis (OMSK), bakteri mencapai telinga tengah melalui tuba Eustachius dari nasofaring atau dari saluran telinga luar melalui membran timpani yang tidak intak. Penyebab mikroorganisme aerob terbanyak OMSK adalah Pseudomonas aeruginosa, Staphylococcus aureus, bakteri Gram-negatif seperti Proteus spp., Klebsiella spp., Escherichia spp., dan Haemophilus influenza. Mikroorganisme anaerob yang paling sering diisolasi adalah Bacteroides spp., dan Fusobacterium spp. Jamur juga diduga berperan dalam OMSK, terutama Aspergilluss spp., dan Candida spp. Dalam beberapa populasi, terutama di tempat yang lembab dan panas di mana jamur dapat berkembang dengan baik, didapatkan jamur 50\% kasus dengan OMSK. ${ }^{7}$

Penatalaksanaan penyakit yang efektif tergantung pada pengetahuan mengenai mikroorganisme penyebab dan sensitivitas mikroba. Telah ditemukan bahwa predominan bakteri penyebab dan pola sensitivitas mikroba berubah dari waktu ke waktu, oleh karena itu, perlu dilakukan pembaruan secara berkala mengenai pola bakteri dari penyebab OMSK sehingga pengobatan terhadap penyakit ini dapat lebih baik lagi. ${ }^{8}$

Departemen THT-KL RSU UKI Jakarta belum memiliki data mengenai pola bakteri OMSK, maka penulis tertarik melakukan penelitian tentang bakteri penyebab OMSK di Poliklinik THT-KL RSU UKI Jakarta.

\section{Bahan dan Cara}


Jenis Penelitian deskriptif, dengan pendekatan secara clinical seriesini dilakukan di Poliklinik THT-KL RSU UKI pada bulan Agustus 2019 - November 2019 dengan populasi penelitian ini adalah seluruh pasien otitis media supuratif kronis yang datang ke Poliklinik THT-KL RSU UKI selama kurun waktu Agustus 2019 - November 2019 dengan kriteria inklusi : semua penderita otitis media supuratif kronis (OMSK) tipe aktif, penderita OMSK yang belum mengonsumsi antibiotik selama satu minggu terakhir, dan bersedia diikutsertakan dalam penelitian ini. Kriteria eksklusi : penderita dengan otore kronik yang bukan karena OMSK. Dalam pengumpulan sekret telinga digunakan kapas lidi steril. Liang telinga dibersihkan dengan kapas lidi steril pertama lalu buang pada tempat infeksius, ambil sekret yang berasal dari kavum timpani diambil pada perforasi membran timpani dengan menggunakan kapas lidi steril, kemudian dimasukkan ke dalam medium Thioglikolat, sebelumnya mulut tabung tersebut dipanaskan di lampu Bunsen lalu tabung ditutup rapat dan diberi label nama.. Thioglikolat yang sudah berisi spesimen dikirim ke Laboratorium Mikrobiologi FK UKI untuk dilakukan pemeriksaan kultur bakteri. Penelitian ini telah mendapat persetujuan dari Komite Etik Fakultas Kedokteran Universitas Kristen Indonesia No.28/Etik Penelitian/FK UKI/2019.

\section{Hasil}

Hasil penelitian disajikan dalam bentuk tabel distribusi frekuensi jenis bakteri yang ditemukan pada penderita OMSK terlihat pada Tabel 1.

Tabel 1. Distribusi Frekuensi Jenis Bakteri Penyebab OMSK.

\begin{tabular}{lcc}
\hline Jenis bakteri & Jumlah & Persentase \\
\hline Gram positif & 6 & $35,3 \%$ \\
Staphylococcus aureus & 2 & $11,8 \%$ \\
Staphylococcus epidermidis & & \\
Gram negatif & & \\
Pseudomonas aeroginosa & 5 & $29,4 \%$ \\
Proteus spp & 1 & $5,9 \%$ \\
Escherichia coli & 1 & $5,9 \%$ \\
Klebsiella spp & 2 & $11,8 \%$ \\
Total & 17 & $100 \%$ \\
\hline
\end{tabular}

Dari 16 penderita, 1 penderita menderita otitis media supuratif kronis (OMSK) di kedua telinganya, sehingga pada penelitian ini terdapat 17 jenis bakteri. Berdasarkan tabel 1 dapat diketahui bahwa dari 17 bakteri yang terbanyak ditemukan adalah Staphylococcus aureus sebanyak 6 (35,3\%) diikuti Pseudomonas aerugenosa 5 (29,4\%), Staphylococcus epidermidis dan Klebsiella spp. masing-masing berjumlah yang sama, yaitu 2 (11,8\%). Proteus spp. dan Escherichia coli masing-masing memiliki jumlah yang sama, yaitu $1(5,9 \%)$. 


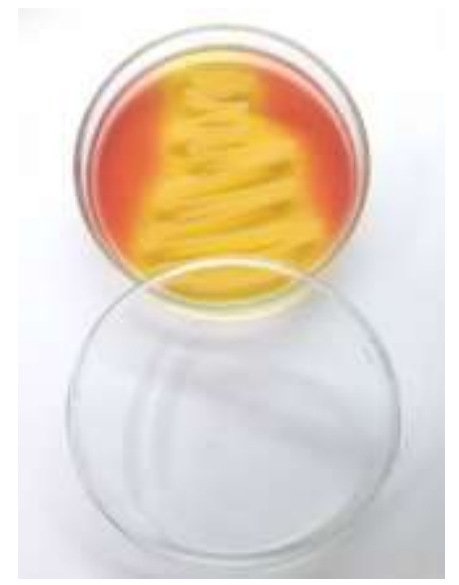

(a)

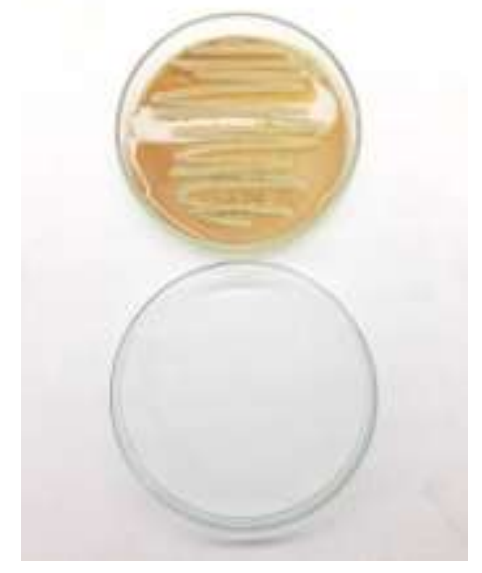

(b)

Gambar 1. (a) Staphylococcus aureus pada media manitol salt agar (MSA),

(b) Staphylococcus aureus pada media nutrient agar (NA)

Pada gambar 1 menerangkan pertumbuhan Staphylococcus aureus pada media agar yang berbeda yang tercatat pada penelitian ini, sebagai bukti adanya pertumbuhan bakteri dengan pengambilan contoh pertumbuhan bakteri terbanyak pada penelitian ini.

\section{Pembahasan}

Sesuai dengan pemaparan tabel 1 , jenis bakteri terbanyak yang ditemukan adalah $S$. aureus $(35,3 \%)$ diikuti $P$. aeroginosa $(29,4 \%)$. Hal ini sama dengan penelitian yang dilakukan di Kathmandu University Hospital, Nepal pada tahun 2010 bakteri penyebab OMSK terbanyak adalah $S$. aureus sebesar 32,2\% diikuti P. aeroginosa sebesar 26,9\%. ${ }^{9}$ Berbeda dengan penelitian di Rajarajeswari Medical College and Hospital, salah satu Rumah Sakit Tipe A di India pada Desember 2012 - November 2013 bakteri penyebab OMSK didominasi oleh $P$. aeroginosa sebesar 33,09\% diikuti S. aureus yaitu sebesar 21,58\%. ${ }^{10}$

Staphylococcus aureus adalah bakteri penghasil enzim katalase yang terlibat dalam berbagai infeksi, seperti lipase, superantigen, exfoliatin untuk menginduksi infeksi, selain itu $S$. aureus memiliki mekanisme agresif menghambat fagositosis. ${ }^{11}$ Berdasarkan Tabel 1 diketahui bahwa $P$. aeroginosa merupakan jenis bakteri yang paling sering ditemukan setelah $S$. aureus. $P$. aeroginosa menggunakan pili untuk melekat pada epitel nekrotik atau jaringan yang rusak pada telinga tengah. Setelah melekat, organisme menghasilkan protease, lipopolisakarida, dan enzim lain untuk mencegah mekanisme sistem imun melawan infeksi. Enzim bakteri dan inflamasi menghasilkan kerusakan yang lebih lanjut, nekrosis dan akhirnya erosi tulang yang mengarah ke beberapa komplikasi OMSK. ${ }^{12}$

Bakteri yang menyebabkan OMSK seperti P. aeroginosa dan S. aureus memiliki bentuk dari biofilm. Biofilm juga telah ditunjukkan pada mukosa telinga tengah anak-anak dengan otitis media kronis, dan pada efusi telinga tengah dari anak-anak dengan otitis media akut berulang yang kemungkinan merupakan faktor risiko untuk OMSK. ${ }^{13,14}$ Biofilm merupakan koloni bakteri yang tumbuh perlahan dan dibungkus suatu lapisan glikopolisakarida yang disebut glycocalyx. Ikatan bakteri dengan permukaan host membentuk biofilm. Biofilm resisten terhadap antibiotik, sehingga sulit diterapi dan karenanya dapat mengakibatkan infeksi berulang. Selain itu biofilm melekat kuat pada jaringan yang rusak, sehingga memperparah masalah eradikasi. ${ }^{15,16}$ Penelitian di RSUD Dr. Soetomo, Surabaya melaporkan 
bakteri biofilm positif didapatkan $75 \%$ pada penderita OMSK tipe bahaya dan $35 \%$ pada penderita OMSK tipe aman, bakteri biofilm negatif didapatkan sebesar $25 \%$ penderita tipe bahaya dan $67,9 \%$ pada tipe aman. Hal ini menunjukkan bakteri biofilm memiliki hubungan bermakna dengan OMSK tipe bahaya. ${ }^{13}$

Pada tabel diatas dapat diketahui Klebsiella spp. berjumlah 2 (11,8\%), Proteus spp., Escherichia coli masing-masing memiliki jumlah yang sama yaitu 1 (5,9\%). Isolasi bakteri Gram negatif Enterobacter seperti E. coli dan Klebsiella spp., Proteus spp. menunjukkan bahwa individu berisiko tinggi terhadap infeksi dari kebersihan yang buruk dan kondisi sanitasi. Dalam studi yang berbeda menunjukkan variasi kultur mikrobiologis yang luas, hal ini dipengaruhi tergantung pada iklim, populasi pasien, dan penggunaan antibiotik. Bagaimanapun, isolasi mikroorganisme sangat membantu bagi perawatan OMSK. ${ }^{9,17}$

\section{Kesimpulan}

Staphylococcus aureus merupakan jenis bakteri terbanyak yang ditemukan pada kultur bakteri OMSK.

\section{Daftar Pustaka}

1. Chronic suppurative otitis media: Burden of illness and management options. World Health Organization.2014. Diunduh dari: https://www.who.int/pbd/publications/Chronicsuppurativeotitis_media.pdf. Accessed on 20 Agustus 2019.

2. Morris P. Chronic Supurative otitis media. BMJ Clin Evid. 2012.

3. Jensen R.G., Koch A., Homoe P. The risk of population with a high prevalence of chronic suppurative otitis media. Int J Pediatr Otorhinolaryngol. 2013;77(9):1530-5.

4. KEMENKES RI. 2013. Riset kesehatan dasar. Diunduh dari :http://www.depkes.go.id/resources/download/general/Hasil\%20Riskesdas\%202013.pdfAccessed on 20 Agustus 2019.

5. Desbassarie F.W., Dermawan A., Hadi S. Profile of patients with complicated chronic suppurative otitis media in Dr. Hasan Sadikin General Hospital Bandung, Indonesia January - December 2011. Althea Med J. 2015:2(1):108-13.

6. Pangemanan D.M., Palandeng O.I., Pelealu O.C.P. Otitis media supuratif kronik di poliklinik T.H.T.K.L., Prof. Dr. R. D. Kandou Manado periode Januari 2014 - Desember 2016. Jurnal e-Clinic. 2018:6(1):.31-5.

7. Verhoeff M., Van der Veen E.L., Rovers M.M., Sanders E.A.M., Schilder A.G.M. Chronic suppurative otitis media; A review. Int J Pediatr Otorhinolaryngol. 2006;70: issue1: 1-12.

8. Ogah S.A., Ogah J.I. Aerobic bacteriology of chronic suppurative otitis media (CSOM) in Federal Medical Centre Lokoja, Nigeria. Nigerian J Pure Appl Sci. 2016;29: 2695-9.

9. Shresta B.L., Amatya R.C.M.., Shresta I., Ghosh I. Microbiological profile of chronic suppurative otitis media. Nepal J ENT Head Neck Surg. SOL Nepal, 2011; 2(2):.6-7.

10. Harshka Y.K., Sangeetha S., Prakash R. Microbiological profile of CSOM and their antibiotic senstivity pattern in tertiarcy care hospital. Int J Curr Microbiol Appl Sci. 2015;4(12):735-43.

11. Mittal R., Debs LH, Patel AP, Nguyen D, Blackwelder P, Yan D, et al. Otopathogenic Staphylococcus aureus invades human middle ear epithelial cells primarily through cholesterol dependent pathway. Sci Report. 2019; 9:1-10.

12. Varughese D. Chronic Suppurative otitis media medical clinical presentation. Diunduh dari: https://emedicine.medscape.com/article/859501-clinical. 20 Agustus 2019.

13. Artono, Purnami N., Rahmawati R. Biofilm bacteria plays a roles in CSOM pathogenesis and has significant correlation with unsafe type csom. Folia Medica Indonesiana. 2015;51(4):208-13.

14. Neeff M., Biswas K., Hoggard M., Taylor M.W., Douglas R. Molecular microbiological profile of chronic suppurative otitis media. J Clin Microbiol. 2016;54(10): 2538-46.

15. Mittal R., Lisi C.V., Gerring R., Mittal J., Mathee K., Narasimhan G., et al. Current concepts in the pathogenesis and treatment of chronic suppurative otitis media. J Med Microbiol. 2015;64(10):1103-16.

16. Edward Y., Novianti D. Biofilm pada otitis media supuratif kronik. Jambi Med J. 2015:3(1): 68-78.

17. Chiwra M., Mulwafu W., Aswani J.M., Masinde J.M., Mkakosya R., Soko D. Microbiology of chronic suppurative otitis media at Queen Elizabeth Central Hospital, Blantyre, Malawi: A cross-sectional descriptive study. Malawi Med J. 2015;27(4): 120-4. 